\title{
Conspecific tolerance and sexual segregation in the use of space and habitats in the European polecat
}

\author{
Thierry LODÉ
}

\begin{abstract}
Lodé T. 1996. Conspecific tolerance and sexual segregation in the use of space and
\end{abstract} habitats in the European polecat. Acta Theriologica 41: 171-176.

Radiotracking of three couples of polecats Mustela putorius Linnaeus, 1758 in wetlands of western France showed that the monthly home ranges of male averaged $0.426 \mathrm{~km}^{2}$ and overlapped the females' ranges which were smaller $\left(0.125 \mathrm{~km}^{2}\right)$. Although the distribution of polecat's localizations in the three main habitats differed significantly between the male and the female, the seasonal overlap of habitat niches $\left(\mathrm{C}_{\mathrm{jk}}\right)$ was considerable and varied from 0.727 to 0.894 . The proportion of simultaneous localizations on the same square averaged $4 \%$ of monthly localizations while $96 \%$ of the localizations indicated solitary activity. Also, the duration of time occuring together was short: only 1.8 days per month on average. The observations suggested that the social organization of $M$. putorius was characterized by periodic variations of intraspecific tolerance between males and females which were probably influenced by hormonal factors during spring and by food availability during summer and autumn. A strong spatio-temporal segregation, however, determined a particularly individual exploitation of the space.

Laboratoire d'Ecologie animale, Université d'Angers, 2 bd Lavoisier, 49045 Angers, France

Key words: Mustela putorius, conspecific tolerance, home range, sexual segregation, space use, habitat preferences

\section{Introduction}

The social organization of mustelids generally seems to be based on a system of a rather strict intrasexual territoriality (Powell 1979); the male defends an almost exclusive territory against other males and the female against other females. On the other hand, a male covers a larger area which most frequently overlaps that of one or several females (Lockie 1966, Erlinge 1977).

Nevertheless, most mustelids live a rather solitary life and direct interactions often remain antagonistic (Poole 1973, 1974). Social phases of life cycle, like reproduction or rearing the young, require an inhibition of the intraspecific intolerance through changes of behaviour (Peters 1984, Lodé 1989, 1990).

Thus, it seemed interesting to check whether the home range overlap between males and females results from a real tolerance or whether there is a strategy of 
avoidance behaviour. Radiotracking of three couples of Mustela putorius Linnaeus, 1758 in the marshes of western France provided information on this aspect. The aim of the study was to specify the level of tolerance and to examine the possibility of a sexual segregation in $M$. putorius.

\section{Material and methods}

Radiotracking was done on two wetlands and on adjoining small woods in western France, Grand-lieu $\left(47^{\circ} 05^{\prime} \mathrm{N}, 1^{\circ} 39^{\prime} \mathrm{W}\right.$ ) and Brière $\left(47^{\circ} 20^{\prime} \mathrm{N}, 2^{\circ} 10^{\prime} \mathrm{W}\right.$ ) (see Lodé 1993,1994$)$. The climate is mild and humid (mean temperature between $6^{\circ} \mathrm{C}$ in winter and $17^{\circ} \mathrm{C}$ in summer, precipitation averaging $800 \mathrm{~mm}$ per year) influenced by the nearby ocean.

Each of three couples of polecats Mustela putorius (Table 1) were fitted with radio-transmitters, and tracked simultaneously. The surveys concern couples, and evidently not a female with its cubs. Localizations were obtained through triangulation with at least one localization an hour plus a localization during diurnal den using a portable reciever and a yagi antenna. Data were transfered to a square of $50 \mathrm{~m}$ a side to take into account the impreciseness of the technique. The area occupied by each individual was evaluated on a monthly basis by the convex polygon method (Mohr 1947) and the proportion of the space overlap was calculated. The proportion of different habitats was measured for each polecat. A description of the main characteristics of the landscape allows us to define a brief typology in three distinct habitats, ie deciduous woods, marshes, and dry meadows. No localization was found in marginal habitats such as cereal field, road, and housing, for each surveyed animal. The overlap index of the habitat niche was calculated following the Schoener $(1968,1974)$ formula $\mathrm{C}_{\mathrm{jk}}=1-0.5 \Sigma \mathrm{Pi}_{\mathrm{j}}-\mathrm{Pi}_{\mathrm{k}}$ in which $\mathrm{Pi}_{\mathrm{j}}$ was the relative proportion of each habitat in the area occupied by the animal $\mathrm{j}$. The index varies from 0 (avoidance) to 1 (complete overlap). When the presence of these individual polecats was simultaneously recorded on the same 50 meters a side quadrat, it was considered that the two animals were together. The number of localizations common refers only to the animals being on the same site. The minimal duration in days, during which individuals presented at least one localization in common, was measured to give an account of occurrence together. Finally the temporal distribution of 19 observations was used to test the simultaneous presence of several individuals at the same place. These observations were made by naturalists and game-keepers, and concerned a total of 48 individuals observed. Comparisons were tested with the $\chi^{2}$, the $U$ of Mann-Whitney or the $H$ of Kruskal-Wallis (Siegel 1956).

Table 1. Characteristics of the 6 radiotracked polecats Mustela putorius in western France.

\begin{tabular}{|c|c|c|c|c|c|c|c|c|}
\hline \multirow[b]{2}{*}{ No } & \multicolumn{4}{|c|}{ Males } & \multicolumn{4}{|c|}{ Females } \\
\hline & $\begin{array}{l}\text { Body } \\
\text { mass } \\
(\mathrm{g})\end{array}$ & $\begin{array}{l}\text { Number of } \\
\text { localizations }\end{array}$ & $\begin{array}{l}\text { Surveyed } \\
\text { period } \\
\text { (days) }\end{array}$ & $\begin{array}{l}\text { Home } \\
\text { range } \\
\left(\mathrm{km}^{2}\right)\end{array}$ & $\begin{array}{l}\text { Body } \\
\text { mass } \\
(\mathrm{g})\end{array}$ & $\begin{array}{l}\text { Number of } \\
\text { localizations }\end{array}$ & $\begin{array}{l}\text { Surveyed } \\
\text { period } \\
\text { (days) }\end{array}$ & $\begin{array}{l}\text { Home } \\
\text { range } \\
\left(\mathrm{km}^{2}\right)\end{array}$ \\
\hline 1 & 1250 & 224 & 83 & 0.824 & 605 & 276 & 131 & 0.392 \\
\hline 2 & 1580 & 235 & 129 & 1.608 & 820 & 132 & 98 & 0.441 \\
\hline 3 & 1500 & 306 & 130 & 1.482 & 680 & 98 & 49 & 0.338 \\
\hline Average & & & & 1.305 & & & & 0.390 \\
\hline $\mathrm{SD}$ & & & & 0.344 & & & & 0.042 \\
\hline
\end{tabular}




\section{Results and discussion}

\section{Overlap in activity areas}

The home range of the males averaged $1.305 \mathrm{~km}^{2}(\mathrm{SD}=0.344)$ and that of females $0.390 \pm 0.042 \mathrm{~km}^{2}$. The monthly area of activity was on average $0.426 \pm$ $0.201 \mathrm{~km}^{2}$ for males while the females used a significantly smaller area reaching $0.125 \pm 0.047 \mathrm{~km}^{2}$ (Table 2). These figures roughly coincided with Nilsson's evaluations $\left(0.2-0.9 \mathrm{~km}^{2} ; 1978\right)$ or Blandford's $\left(1.1 \mathrm{~km}^{2} ; 1987\right)$. The polecat's preference for rivers or wet areas (Danilov and Rusakov 1969, Blandford 1987, Lodé 1991, 1993, Jędrzejewski et al. 1993) could also lead to a linear shape of the home ranges expending $3 \mathrm{~km}$ along the banks (Brzeziński et al. 1992). Under more severe climatic conditions like in the Karely or in the Swiss Alps, the home range could cover an extensive area (more than $11 \mathrm{~km}^{2}$ ), suggesting a kind of nomadism (Danilov and Rusakov 1969, Weber 1989). In western France the polecats tended to exploite a larger area during autumn and winter than during spring and summer $(H=7.16, p=0.06$; see Table 2$)$.

Range overlap between males and females reached $30.7 \%$ on average without any significant difference among the couples (males: $H=1.41$, ns, females: $H=$ $2.95, \mathrm{~ns})$. The overlap seemed more significant in spring (43\%) and autumn $(29.5 \%)$ than in summer $(17 \%)$ or in winter $(25 \%)$. An overlap of a female's range by a male has been observed in often studies in polecats (Weber 1989, Lodé 1991, 1993, Brzeziński et al. 1992). This overlap of the areas frequented by the male and the female seems characteristic for several mustelids (Erlinge 1974, Powell 1979, Zalewski et al. 1995). The differences in the number of localizations show that marshes were significantly more exploited in spring (55.7) and in summer (52.6) while woods were more frequented in winter (59.4) and in autumn $\left(48.2, \chi^{2}=64.7\right.$, $p<0.0001$ ). In fact, the exploitation of woody and wet areas was associated with consumption of small rodents and anurans respectively (Weber 1989, Lodé 1991, Jędrzejewski et al. 1993, Lodé 1994). In western France, the distribution of localizations in the frequented habitats significantly differed between male and female polecats $\left(\chi^{2}=29.6, \mathrm{df}=2, p<0.001\right.$; Fig. 1$)$ whatever the considered couple

Table 2. Seasonal variations of the monthly home ranges $\left(\mathrm{km}^{2}\right)$ used by 6 radiotracked polecats in western France (number of localizations are given in brackets).

\begin{tabular}{lcccccr}
\hline & Winter & Spring & Summer & Autumn & Mean & Mann-Whitney $U$-test \\
\hline Males & 0.629 & 0.261 & 0.300 & 0.494 & 0.426 & \\
SD & 0.177 & 0.141 & 0.114 & 0.018 & 0.201 & \\
& $(268)$ & $(253)$ & $(138)$ & $(107)$ & $(765)$ & \\
& & & & & & $U=7, p<0.002$ \\
Females & 0.124 & 0.110 & 0.100 & 0.125 & 0.125 & \\
SD & 0.028 & 0.012 & 0.010 & 0.035 & 0.047 & \\
& $(71)$ & $(110)$ & $(87)$ & $(238)$ & $(506)$ & \\
\hline
\end{tabular}




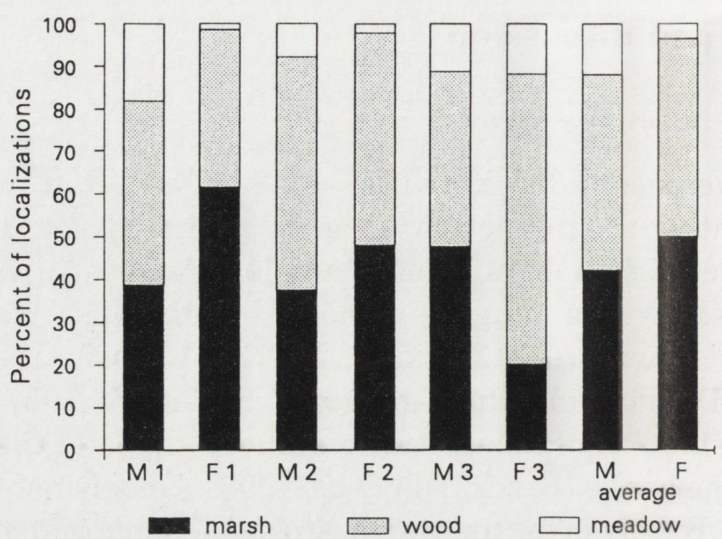

Fig. 1. Distribution of polecats' localizations considering the main habitats: marsh, wood, and meadow. $\mathrm{M}$ - male, $\mathrm{F}$ - female.

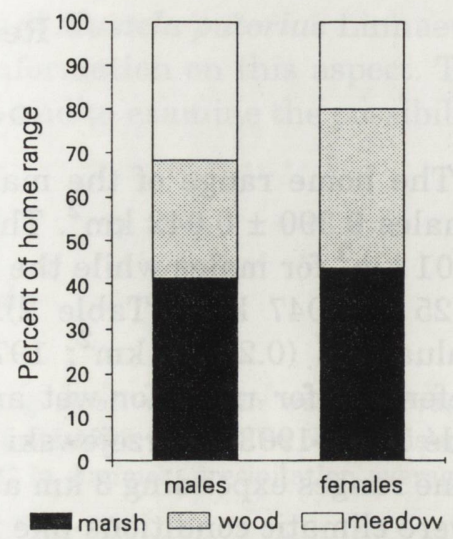

Fig. 2. Proportions of the area utilized by polecats considering the three main habitats.

(couple 1: $\chi^{2}=51.6, p<0.0001$, couple $2: \chi^{2}=7.52, p<0.02$, couple $3: \chi^{2}=24.5$ $p<0.0001$.). Nevertheless, the overlap index concerning the different habitats varied: $\mathrm{C}_{\mathrm{jk}}=0.779$ for marshes, $\mathrm{C}_{\mathrm{jk}}=0.894$ for woods and $\mathrm{C}_{\mathrm{jk}}=0.727$ for meadows, depending on the considered couple. Moreover, the proportion of habitats in the activity area did not really differ between males and females (Fig. $2 ; U=48.5$, ns for marshes, $U=41.5$, ns for woods, $U=37$, ns for meadows). Thus, it seemed that the female avoided making use of the sectors most frequented by the males. Erlinge (1974) also noticed the existence of a temporal segregation in the stoat Mustela erminea.

\section{Common space utilization}

Males and females were rarely located simultaneously in the same square (5\%, 24 observations out of 453 localizations) and the average proportion of localizations with animals together represented only $4.6 \%(\mathrm{SD}=5.7)$ of the monthly localizations without any significant difference among the couples $(H=0.45$, ns; Fig. 3$)$. In fact, the duration of the period in which the activity took place on the same areas did not exceed 1.8 days a month $(\mathrm{SD}=1.9)$ on average without a significative difference among the couples $(H=1.85, \mathrm{~ns})$. The longest duration observed in summer corresponded to the communal use of the same diurnal den. This intraspecific tolerance was particularly obvious during March in western France and corresponded to the breeding period (Saint-Girons 1973, Audy 1976, Lodé 1990). Nonetheless, in May and June, females once again displayed a certain cautiousness towards their conspecific polecats and did not simultaneously use the same area as the males. Such a behaviour seemed to favour the protection of the litter after the parturition. Moreover, the observation of an agonistic interaction suggests social dominance change in favour to females. In summer and the 


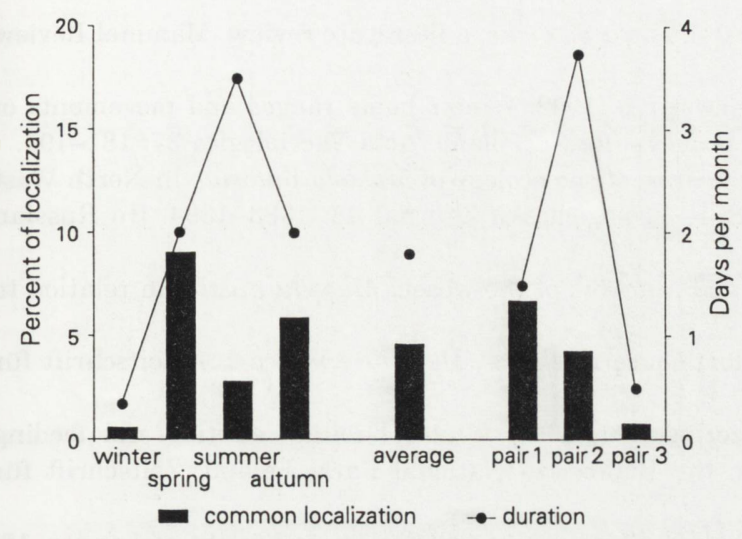

Fig. 3. Monthly proportions of localizations when polecats were simultaneously in the same square, (histogram) and mean duration in days of the common use of an area (curve line).

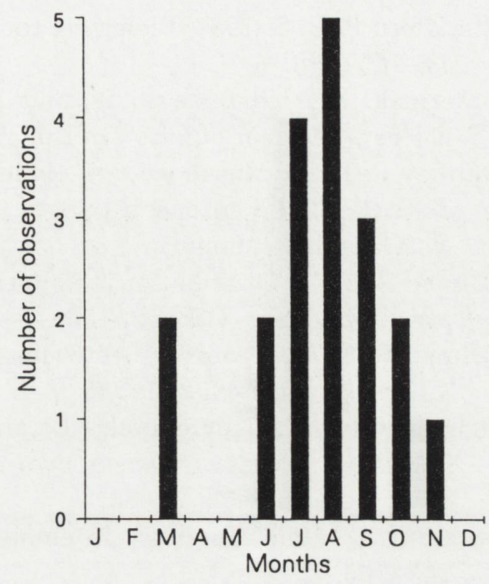

Fig. 4. Monthly variations in number of observations $(n=19)$ of several polecats seen together in western France.

beginning of autumn, there was an increase of tolerance, the number of observations of several polecats together was significantly more frequent $(H=8.2 p<$ $0.042, n=19$ ). The young could live together, until autumn, with an adult female and this relationship let suppose that familial links remained during this period (Lodé 1993). Pulliainen (1984) made the same observation on Martes martes.

In fact the increase of food resources during this period could also constitute a decisive factor. In western France summer and autumn coincided with an increase in the abundance of voles and of rabbits for the most part (Lodé 1991, 1994). Thus, these periods of intraspecific tolerance were still limited in time and seemed to be linked to the influence of reproductive hormonal factors or to the increasing of trophic availabilities. Nonetheless, animals regularly showed a strategy of spatio-temporal avoidance, even between male and female. Habitat use remained very selective and the predation centered on zones of strong trophic potentialities (Weber 1989, Jędrzejewski et al. 1993, Lodé 1994). The polecat's individualism, thus, constituted a response particularly adapted to the regular exploitation of inequally distributed out resources. It seems reasonable to conclude that this segregation of the space frequentation leads to a social organization characterized by a very individualistic strategy of environment use.

Acknowledgements: My thanks to F. Cupertino, F. Desprez, B. Fraboulet, C. Gaigeard, B. Guillemot, M. Harouet, J. Hedin, F. Ibanez, D. Lacourpaille, D. Le Jacques, A. M. O'Donovan, M. Pondaven, C. Redou and J. Y. Robert.

\section{References}

Audy M. C. 1976. Le cycle sexuel saisonnier du mâle des Mustélidés européens. General and Comparative Endocrinology 30: 117-127. 
Blandford P. R. S. 1987. Biology of the polecat Mustela putorius: a literature review. Mammal Review 17: 155-198.

Brzeziński M., Jędrzejewski W. and Jędrzejewska B. 1992. Winter home ranges and movements of polecats Mustela putorius in Białowieża primeval forest, Poland. Acta Theriologica 37: 181-191.

Danilov P. I. and Rusakov O. S. 1969. Peculiarities of the ecology of Mustela putorius in North West districts of the european part of the USSR. Zoologicheskiï Zhurnal 48: 1383-1394. [In Russian with English summary]

Erlinge S. 1974. Distribution, territoriality and numbers of the weasel Mustela nivalis in relation to prey abundance. Oikos 25: 308-314.

Erlinge S. 1977. Agonistic behaviour and dominance in stoats (Mustela erminea L.). Zeitschrift für Tierpsychologie 44: 375-388.

Jędrzejewski W., Jędrzejewska B. and Brzeziński M. 1993. Winter habitat selection and feeding habits of polecats (Mustela putorius) in the Białowieża National Park, Poland. Zeitschrift für Säugetierkunde 58: 75-83.

Lockie J. D. 1966. Territory in small carnivores. Symposia of the Zoological Society of London 18: $143-165$.

Lodé T. 1989. Ontogénèse des comportements de prédation et rôle de l'expérience alimentaire précoce chez Mustela putorius. Mammalia 53: 497-509.

Lodé T. 1990. Reconnaissance du congénère et comportement sexuel chez le putois. Bulletin de la Société des Sciences Naturelles de l'Ouest de la France 12: 105-110.

Lodé T. 1991. Exploitation des milieux et organisation de l'espace chez deux mustélidés européens, la fouine et le putois. Vie Milieu 41: 29-38.

Lodé T. 1993. Stratégies d'utilisation de l'espace chez le putois européen Mustela putorius L. dans l'ouest de la France. Revue d'Ecologie (Terre Vie) 48: 305-322.

Lodé T. 1994. Environmental factors influencing habitat exploitation by the polecat Mustela putorius in western France. Journal of Zoology, London 234: 75-88.

Mohr C. O. 1947. Table of equivalent population of North American small mammals. American Midland Naturalist 37: 223-249.

Nilsson T. 1978. Home-range utilization and movements in the polecat Mustela putorius during autumn. International Theriological Congress, Brno 2: 173.

Peters G. 1984. On the structure of friendly close range vocalizations in terrestrial carnivores (Mammalia: Carnivora: Fissipedia). Zeitschrift für Säugetierkunde 49: 157-182.

Poole T. B. 1973. The aggressive behaviour of individual male polecats Mustela putorius, $M$. furo and hybrids towards familiar and unfamiliar opponents. Journal of Zoology, London 170: 395-414.

Poole T. B. 1974. Detailed analysis of fighting in polecats (Mustelidae) using cine film. Journal of Zoology, London 173: 396-393.

Powell R. A. 1979. Mustelids spacing patterns: variations on a theme by Mustela. Zeitschrift für Tierpsychologie 50: 153-155.

Pulliainen E. 1984. Use of the home range by Pine martens Martes martes. Acta Zoologica Fennica 171: 271-274.

Saint-Girons M. C 1973. Les mammiferes de France et du Benelux. Doin, Paris. 1-481.

Schoener T. W. 1968. The Anolis lizards of Bimini: resource partitioning in a complex fauna. Ecology 49: 704-726.

Schoener T. W. 1974. Resource partitioning in ecological communities. Science 185: 27-39.

Siegel S. 1956. Nonparametric statistics for the behavioural sciences. MacGraw-Hill, New York: 1-301.

Weber D. 1989. Foraging in polecats (Mustela putorius L.) of Switzerland: The case of a specialist anuran predator. Zeitschrift für Säugetierkunde 54: 377-392.

Zalewski A., Jędrzejewski W. and Jędrzejewska B. 1995. Pine marten home ranges, numbers and predation on vertebrates in a deciduous forest (Białowieża National Park, Poland). Annales Zoologi Fennici 32: 131-144.

Received 13 November 1995, accepted 18 March 1996. 